\title{
Determinan Maternal Kejadian Pre Eklampsi Pada Ibu Hamil Trimester III Di RS Prima Husada Sidoarjo
}

\author{
Nur Masruroh, Fauziyatun Nisa \\ Prodi D3 Kebidanan, Fakultas Keperawatan dan Kebidanan, Universitas Nahdlatul Ulama \\ Email : masruroh@unusa.ac.id
}

\begin{abstract}
Abstrak
Preeklampsia merupakan suatu kondisi hipertensi pada periode kehamilan khusus yang secara signifikan berpengaruh pada angka morbiditas dan mortalitas ibu di seluruh penjuru dunia. Tujuan dari penelitian ini adalah untuk menganalisis determinan maternal kejadian preeklampsi pada ibu hamil trimester III . Metode penelitian cross sectional dengan populasi dan sampel nya adalah seluruh ibu hamil trimseter III yang datang periksa di RS Prima Husada Sidoarjo pada bulan Mei-Juli 2020. Analisa data menggunakan t hitung sampel tunggal. Hasil penelitian didapatkan nilai tertinggi sampai dengan terendah untuk determinan maternal kejadian preeklampsi adalah: usia $(19,675)$ dan $p$ value $=0,001(<0,005)$, mean arterial pressure $(18,943)$ dan $p$ value $=0,002$, protein urine $(17,245) p$ value $=0,001(<0,005)$, paritas $(16,654) p$ value $=0,000(<0,005)$, riwayat hipertensi $(11,489) \mathrm{p}$ value $=0,001 \quad(<0,005)$ dan kunjungan antenatal care $(9,143) \mathrm{p}$ value $=0,000(<0,005)$. Keseluruhan determinan tersebut terbukti sebagai faktor risiko kejadian preeklampsi pada ibu hamil trimester III di RS Prima Husada Sidoarjo. Pentingnya melakukan deteksi dini secara rutin untuk mencegah komplikasi pada masa kehamilan dan menghindari determinan kejadian preeklampsi pada ibu hamil.
\end{abstract}

Kata kunci : determinan, ibu hamil, preeklampsi

\begin{abstract}
Abstrack
Preeclampsia is a hypertensive condition in the special period of pregnancy that significantly affects maternal morbidity and mortality throughout the world. The purpose of this study was to analyze the maternal determinants of the incidence of preeclampsia in third trimester pregnant women. The research method was cross sectional with the population and sample being all third trimester pregnant women who came to see the Prima Husada Hospital Sidoarjo in May-July 2020. The data analysis used a single sample t-count. The results showed that the highest to the lowest values for maternal determinants of the incidence of preeclampsia were: age $(19.675)$ and $p$ value $=0.001(<0.005)$, mean arterial pressure $(18.943)$ and $p$ value $=$ 0.002 , urine protein $(17.245) \mathrm{p}$ value $=0.001(<0.005)$, parity $(16.654) \mathrm{p}$ value $=0.000(<0.005)$ history of hypertension $(11.489) \mathrm{p}$ value $=0.001(<0.005)$ and antenatal care visits $(9.143) \mathrm{p}$ value $=0.000(<0.005)$. All of these determinants are proven to be risk factors for the incidence of preeclampsia in third trimester pregnant women at Prima Husada Hospital Sidoarjo. The importance of routine early detection to prevent complications during pregnancy and to avoid the determinants of the incidence of preeclampsia in pregnant women
\end{abstract}

Key words: determinants, pregnant women, preeclampsia

http://ejournal.urindo.ac.id/index.php/kesehatan

Article History : 


\section{PENDAHULUAN}

Masalah kesehatan masyarakat bersifat holistik dan saling terkait dengan masalah selain kesehatan itu sendiri. Faktor-faktor yang mempengaruhi kesehatan dan mempengaruhi status kesehatan adalah lingkungan, perilaku, perawatan kesehatan, dan genetik. Jika faktor-faktor ini dalam kondisi baik pada saat yang sama, keadaan kesehatan tercapai secara optimal optimal (Yuniarti et al., 2017).

Kematian ibu merupakan indikator risiko yang dihadapi wanita selama kehamilan dan persalinan. Kematian ibu yang tinggi menunjukkan kondisi ekonomi yang buruk dan akses ke layanan medis, termasuk layanan prenatal dan obstetrik. Salah satu penyebab kematian ibu adalah terbatasnya akses terhadap pelayanan kesehatan ibu yang berkualitas. Layanan darurat diberikan tepat waktu, terutama karena keterlambatan dalam mengenali tanda-tanda bahaya dan membuat keputusan. Keterlambatan dalam mendapatkan fasilitas medis dan menerima perawatan medis (RI, 2018).

Preeklamsia adalah gangguan hipertensi khusus untuk kehamilan dan memiliki dampak yang signifikan terhadap morbiditas dan mortalitas ibu di seluruh dunia. Ini terjadi pada $5-7 \%$ dari semua kehamilan dan merupakan penyebab utama kematian ibu di negara berkembang. Karena preeklamsia dikaitkan dengan kelahiran prematur atau jatuh di dalam rahim, itu juga merupakan faktor penting dalam morbiditas dan mortalitas perinatal. Ada banyak faktor risiko yang mempengaruhi perkembangan preeklamsia, termasuk usia, riwayat persalinan, preeklamsia sebelumnya, riwayat keluarga preeklamsia, kehamilan ganda, masalah kesehatan yang sudah ada kondisi kesehatan seperti diabetes, tekanan darah tinggi kronis, gangguan autoimun, dan interval antara preeklamsia (Fatkhiyah et al., 2016).

Baik preeklamsia maupun preeklamsia merupakan komplikasi kehamilan yang sedang berlangsung, dengan gejala khas hipertensi, edema, dan protein urin. Komplikasi preeklamsia (PE) maternal dan neonatal seperti tersedak, berat badan lahir rendah, dan kematian perinatal. Beberapa faktor ibu merupakan faktor risiko PE, seperti usia ibu yang terlalu muda atau terlalu tua (ibu hamil berusia 20 atau 35 tahun), fertilitas yang tinggi, usia kehamilan, riwayat kesehatan dan riwayat obstetrik, Mollahidatidosa dan hidramnion. Hipotesis preeklamsia meliputi iskemia dan predisposisi plasenta yaitu diabetes, mola sporogenik, obesitas, hidrosefalus janin, dan hidrosefalus (Kusumawati \& Ratna Wijayanti, 2017).

Penelitian ini untuk menganalisis determinan terjadinya preeklampsia pada ibu hamil trimester III di RS Prima Husada Sidoarjo

\section{METODE PENELITIAN}

Jenis penelitian ini adalah studi observasional cross-sectional yang dilakukan untuk menganalisis determinan maternal ibu (usia, 
riwayat ibu, riwayat hipertensi, frekuensi konsultasi antenatal, tekanan arteri rata-rata dan protein urin). Penelitian ini dilakukan pada bulan Mei sampai Juli 2020. Populasi penelitian ini adalah seluruh ibu hamil yang berkunjung ke RS Prima Husada Sidoarjo. Sampel 30 orang tersangka secara simple random sampling. Pengumpulan data menggunakan data sekunder yang diperoleh dari buku KIA dan data primer diperoleh dengan menghitung mean arterial pressure dan mengukur konsentrasi protein urin menggunakan metode dipstick.

\section{HASIL PENELITIAN}

Tabel 1 Distribusi Frekuensi Responden Berdasarkan Usia, Paritas, Riwayat hipertensi, kunjungan ANC, MAP dan Protein urine

\begin{tabular}{lll}
\hline Variabel & $\mathrm{n}$ & $\%$ \\
\hline Usia & 0 & 0 \\
$<20$ tahun & 21 & 70 \\
$20-35$ tahun & 9 & 30 \\
$>35$ tahun & 13 & \\
\hline Paritas & 17 & 43,4 \\
Primigravida & & 56,6 \\
Multigravida & 4 & 13,3 \\
\hline Riwayat hipertensi & 26 & 86,7 \\
Ya & & \\
Tidak & 18 & 60 \\
\hline Kunjungan ANC & 12 & 40 \\
Teratur & & \\
Tidak & 22 & 73,3 \\
\hline Mean Arterial Pressure & 7 & 26,7 \\
Positif & 10 & 33,4 \\
Negatif & 20 & 66,6 \\
\hline Protein Urine & \\
Positif & Negatif &
\end{tabular}

Sumber : data Primer dan Sekunder 2020

Tabel 2 Analisis uji t sampel tunggal

\begin{tabular}{|c|c|c|c|c|c|}
\hline \multirow[t]{2}{*}{ Variabel } & \multirow[t]{2}{*}{$\mathrm{t}$} & \multirow[t]{2}{*}{$d f$} & \multirow[t]{2}{*}{ Sig.(2-tailed) } & \multicolumn{2}{|c|}{$95 \% \mathrm{Cl}$ of the difference } \\
\hline & & & & Lower & Upper \\
\hline Usia & 19.765 & 92 & .001 & 1.03 & 1.32 \\
\hline Paritas & 16.654 & 92 & .000 & .74 & .97 \\
\hline $\begin{array}{l}\text { Riwayat } \\
\text { hipertensi }\end{array}$ & 11.489 & 92 & .001 & .57 & .71 \\
\hline Kunjungan ANC & 9.143 & 92 & .000 & .34 & .55 \\
\hline $\begin{array}{l}\text { Mean arterial } \\
\text { Pressure }\end{array}$ & 18.943 & 92 & .002 & .80 & 1.05 \\
\hline Protein urine & 17.245 & 92 & .001 & .63 & .88 \\
\hline
\end{tabular}


Sumber : analisis SPSS

Dari tabel 2 diatas terlihat bahwa usia memiliki $\mathrm{p}$ value $=0,01(<0,05)$, paritas $\mathrm{p}$ value $=0,00(<0,05)$, riwayat hipertensi $\mathrm{p}$ value $=$ $0,01(<0,05)$, kunjungan ANC p value $=0,00$ $(<0,05)$, mean arterial pressure $p$ value $=0,02$ $(<0,05)$ dan protein urine $p$ value $=0,01$ $(<0,05)$. Artinya determinan kejadian preeklampsi tersebut berisiko terhadap terjadinya preeklampsi. Dilihat dari nilai $\mathrm{t}$ hitung, nilai tertinggi adalah usia dan yang terkecil adalah kunjungan ante natal care. Secara berurutan kualitas determinan kejadian preeklampsi menurut nilai $t$ hitungnya adalah sebagai berikut : 1) usia; 2)mean arterial pressure; 3)protein urine; 4)paritas; 5)riwayat hipertensi dan ;6) kunjungan ANC.

\section{PEMBAHASAN}

1. Usia

Dari 30 responden penelitian, sebagian besar (70\%) responden usianya berada di rentang 20-35 tahun, kurang dari setengah (30\%) responden berusia $\geq 35$ tahun dan tidak ada (0\%) responden yang berusia $\leq 20$ tahun. Dari analisis didapatkan nilai $\mathrm{t}$ hitung untuk umur adalah 19,765 dengan tingkat kemaknaan $p=0,001 \quad(<0,005)$ yang artinya usia merupakan determinan dari kejadian preeklampsi dan eklampsi. Usia menempati nilai tertinggi dalam t hitung sebagai determinan penyebab preeklampsi dan eklampsi pada ibu hamil trimester III di RS Prima Husada Sidoarjo.

Penelitian Asmana di tahun 2015 menyatakan bahwa kebermaknaan hubungan usia dengan preeklampsi telah diuji menggunakan ratio prevelance dan chi square test. Didapatkan hasil bahwa terdapat hubungan antara usia dengan preeklamsi dengan nilai $p=0,014(<0,05)$ dengan usia <20 tahun dan >35 tahun adalah sebagai faktor risiko $(R P=1,476$; $\mathrm{Cl}=1,094-1,922)$. Hal ini berarti proporsi terbanyak kejadian preeklampsi pada kelompok usia $<20$ tahun. (Rahmaningtyas et al., 2018)

Sesuai dengan penelitian Situmorang di tahun 2016 yang menyatakan bahwa usia berhubungan secara signifikan dengan kejadian preeklampsi pada ibu hamil dengan nilai $p$ value $=0,000$ $(<0,005)$. Usia merupakan bagian penting dari status kesuburan. Usia dikaitkan dengan peningkatan atau penurunan fungsi tubuh, yang mempengaruhi kesehatan individu. Usia paling aman dan ideal untuk hamil dan melahirkan adalah 20 hingga 35 tahun. Kedua, remaja putri dengan kehamilan pertama dan wanita hamil di atas 35 tahun memiliki risiko lebih tinggi terkena preeklamsia (Dan et al., 2018).

Usia 20-35 tahun, cukup untuk hamil dan melahirkan. Pada usia ini alat 
kelamin sudah matang dan siap menerima kehamilan dan tidak ada masalah selama kehamilan. Jika wanita berada di rentang usia di bawah 20 tahun, maka akan berisiko mengalami preeklamsia selama kehamilan karena organ reproduksi wanita belum siap. Di sisi lain, ibu hamil setelah usia 35 tahun juga lebih rentan mengalami preeklamsia karena perubahan elastisitas jaringan tubuh (Sari et al., 2014).

2. Mean arterial pressure

Dari 30 responden, lebih dari setengah $(73,3 \%)$ responden memiliki hasil pemeriksaan mean arterial pressure negatif. Sedangkan sisanya (26,7\%) positif hasil pemeriksaan mean arterial pressure nya. Analisis nilai dengan $\mathrm{t}$ hitung didapatkan hasil 18,943 dengan tingkat kemaknaan $p=0,002 \quad(<0005)$. Artinya mean arterial pressure merupakan determinan dari kejadian preeklampsi. Mean arterial pressure menempati urutan tertinggi kedua dari hasil nilai $t$ hitung sebagai penyebab preeklampsi pada ibu hamil trimester III di RS Prima Husada Sidoarjo.

Sejalan dengan penelitian Nur di tahun 2020, yang menyatakan bahwa terdapat hubungan antara mean arterial pressure dengan kejadian hipertensi pada ibu hamil dengan tingkat kemaknaan $p=0,000(<0,005)$. (Masruroh, 2020)
Penelitian Rumelia di tahun 2018 ini juga menyatakan bahwa pemeriksaan mean arterial pressure mempunyai nilai prognostik terhadap hipertensi pada kehamilan dinyatakan dengan nilai $p$ pada uji Hosmer dan Lemeshow 0,678 menunjukkan model ini terkalibasi dengan sangat baik karena $p>0,05$. Model ini mempunyai nilai AUC sebesar 0,892 (IK 95\% 0,826-0,957; $p=0,001$ ), sensitivitas $81,8 \%$, spesifisitas 84,1 , nilai duga positif $83,7 \%$ dan nilai duga negatif $82,2 \%$.(Mutiara et al., 2018)

Penelitian menunjukkan hasil yang serupa dengan IP arteri uterine bahwa terjadi peningkatan mean arterial presure secara signifikan pada usia kehamilan 1113 minggu pada wanita yang mengalami preeklampsi demikian juga terdapat korelasi linear negatif yang signifikan antara mean arterial pressure dengan usia kehamilan saat melahirkan(Kurniadi et al., 2017)

Nilai mean arterial pressure didapatkan dengan cara mengukur tekanan darah seperti biasanya kemudian selanjutnya dihitung dengan rumus tekanan darah sistolik ditambah dengan dua kali tekanan darah diastolik dibagi tiga. Dikatakan normal bila didapatkan hasil antara 70-99 mmhg dan dikatakan berisiko bila nilai mean arterial pressure $>99$ mmhg(Fillandro et al., 2019) 
Hipertensi terjadi sebagai akibat dari terjadinya vasokonstriksi dan penurunan tekanan vaskuler perifer. Meskipun hipertensi sebagai tanda kedua dari preeklampsi, ini juga penting sebagai indikasi dini terjadinya preeklampsi. Pemeriksaan tekanan darah yang akurat diperlukan, selain itu perlu juga diperhatikan hal -hal sebagai berikut: a) pemeriksaan tekanan darah yang pertama biasanya yang paling tinggi, biasanya akan menurun setelah pasien beradaptasi dengan prosedur dan lingkungan; b) penggunaan spigmomanometer raksa merupakan gold standar; 3) penggunaan ukuran cuff yang tepat; 4) posisi lengan dan postur tubuh saat diperiksa(Phillips et al., 2017)

Pada umumnya semua ibu hamil mengalami perubahan fisiologis yang terjadi untuk mempertahankan kehamilan yang normal. Salah satu perubahan fisik yang terjadi adalah perubahan pada sistem kardiovaskuler. Curah jantung meningkat 20\% pada usia kehamilan 8 minggu, memungkinkan terjadinya vasodilatasi perifer. $\mathrm{Hal}$ ini dipengaruhi oleh sel-sel endotel, yang mengandung sintesis oksida nitrat diatur oleh estradiol dan prostaglandin (PGI2). Vasodilatasi perifer mengkompensasi hal ini dengan mengurangi resistensi vaskular sistemik sebesar $25-30 \%$ selama kehamilan dan meningkatkan curah jantung sebesar $40 \%$. Hal ini terutama dicapai dengan penurunan volume sekuncup dan peningkatan denyut jantung. Curah jantung maksimum tercapai pada usia kehamilan sekitar 20 sampai 28 minggu. Pada kenyataannya tidak semua ibu hamil mampu beradaptasi dengan perubahan fisiologis yang terjadi selama kehamilan, sehingga yang terjadi adalah kondisi patologis dimana perubahan fisiologis tersebut terganggu (Fajarsari et al., 2016).

3. Protein Urine

Dari 30 responden, lebih dari setengah $(66,6 \%)$ responden protein urine nya positif dan sisanya $(33,4 \%)$ responden protein urine nya negatif. Dari analisis didapatkan nilai $\mathrm{t}$ hitung untuk protein urine adalah 17,245 dengan tingkat kemaknaan $p=0,001 \quad(<0,005)$ yang artinya protein urine merupakan determinan dari kejadian preeklampsi dan eklampsi. Protein urine menempati nilai tertinggi ketiga dalam $t$ hitung sebagai determinan penyebab preeklampsi dan eklampsi pada ibu hamil trimester III di RS Prima Husada Sidoarjo. Hal ini tidak sejalan dengan penelitian yang dilakukan Mutiara dkk di tahun 2018 yang menyatakan bahwa terdapat hubungan yang signifikan antara protein urine dengan hipertensi dengan nilai $p=$ $<0,000$ (Fajarsari et al., 2016) 
Tetapi tidak sejalan dengan hasil penelitian tersebut menurut Kurniadi di tahun 2017 yang menyatakan bahwa status hipertensi tidak berhubungan dengan kadar protein dalam urine dengan nilai $p=>0,000$ (Asmana et al., 2016)

Urin protein positif dihasilkan dari asupan protein yang berlebihan, demam, aktivitas fisik yang intens, penyakit ginjal, dan infeksi saluran kemih. Faktor penyebab proteinuria adalah filtrasi glomerulus dan reabsorpsi protein koroner. Proteinuria adalah protein yang diekskresikan dalam urin dengan kecepatan 30 hingga $150 \mathrm{mg}$ atau lebih per hari, dan proteinuria adalah salah satu tanda penyakit ginjal. Jumlah protein yang tidak normal merupakan tanda awal penyakit ginjal yang serius. Proteinuria adalah iskemik sementara dan dapat dilanjutkan (Yuniantika et al., n.d.).

Pemeriksaan protein urine diperlukan untuk menegakkan diagnosa preeklampsi, tetapi derajat preeklampsi ringan ataupun berat tidak bisa ditentukan dari kadar protein dalam urine. Tetapi saat ditemukan adanya kasus dengan protein urine yang terdeteksi melebihi batas normal petugas kesehatan harus waspada adanya kemungkinan terjadinya komplikasi pada ibu dan janin.(Fatkhiyah et al., 2016)
4. Paritas

Dari 30 responden, lebih dari setengahnya $(56,6 \%)$ responden adalah multiparitas atau multigravida yaitu ibu yang hamil anak kedua atau lebih dan sisa $(43,4 \%)$ responden adalah ibu yang baru hamil untuk pertama kalinya atau primigravida. Dari analisis didapatkan nilai t hitung untuk paritas adalah 16,654 dengan tingkat kemaknaan $p=0,000$ $(<0,005)$ yang artinya paritas merupakan determinan dari kejadian preeklampsi dan eklampsi. Paritas menempati nilai tertinggi keempat dalam $\mathrm{t}$ hitung sebagai determinan penyebab preeklampsi dan eklampsi pada ibu hamil trimester III di RS Prima Husada Sidoarjo.

Dengan nulipara, risiko berkembangnya preeklamsia hampir tiga kali lebih tinggi. Sekitar 85\% kasus preeklamsia terjadi selama kehamilan pertama. Anak kedua dan ketiga adalah yang paling aman dalam hal kejadian preeklamsia, dan risikonya meningkat lagi dengan penyakit parah. Memang, kehamilan pertama membentuk "antibodi penghambat" terhadap antigen yang belum matang. Pada awal kehamilan, "protein human leukocyte antigen (HLA)" terbentuk yang memainkan peran penting dalam penolakan ibu terhadap produk kehamilan dan dalam pengaturan respons imun yang membuat ibu tidak 
toleran terhadap beban plasenta. Preeklamsia (Situmorang et al., 2016).

Persalinan pertama melibatkan pengetahuan dan pengalaman yang terbatas tentang perawatan ibu ibu. Liter kedua dan ketiga adalah yang paling aman. Paritas 1 atau lebih tinggi ( 3 atau lebih tinggi) memiliki risiko tinggi kelahiran prematur. Ibu di atas usia empat tahun sering mengalami gangguan fungsi reproduksi karena sibuk mengurus rumah, merasa lelah, dan kurang memperhatikan kondisi tempat tinggal (nutrisi dan perkembangan fisik) (Situmorang et al., 2016)

Pembuktian hubungan paritas dengan preeklampsi pada penelitian yang dilakukan oleh Asmana 2016, dilakukan dengan uji statistik chi square test dan ratio prevelance. Berdasarkan ratio prevelance didapatkan didapat kesimpulan bahwa belum dapat ditentukan apakah pada nullipara merupakan sebuah faktor risiko atau faktor protektif dari kejadian preeklampsi $(\mathrm{RP}=0,765 ; \mathrm{Cl}=0,565-1,034)$. Hasil analisis menggunakan chi square menunjukkan tidak adanya antara paritas dengan preeklampsi berat ( $p$ value= 0,096)(Yuniarti et al., 2017)

5. Riwayat Hipertensi

Dari 30 responden, sebagian besar $(86,7 \%)$ tidak memiliki riwayat hipertensi, hanya $13,7 \%$ responden yang memiliki riwayat hipertensi. Dari analisis didapatkan nilai $\mathrm{t}$ hitung untuk riwayat hipertensi adalah 11,489 dengan tingkat kemaknaan $p=0,001 \quad(<0,005)$ yang artinya riwayat hipertensi merupakan determinan dari kejadian preeklampsi dan eklampsi. Riwayat hipertensi menempati nilai tertinggi kelima dalam $\mathrm{t}$ hitung sebagai determinan penyebab preeklampsi dan eklampsi pada ibu hamil trimester III di RS Prima Husada Sidoarjo.

Perempuan yang memiliki riwayat preeklampsia pada kehamilan pertama memiliki risiko 7 kali lebih besar untuk mengalami preeklampsi pada kehamilan kedua dan seterusnya. Setiap kasus hipertensi tidak selalu didapat dari garis keturunan tetapi setiap orang mempunyai potensi untuk mendapat bila orangtua juga mengidap hipertensi. Kemungkinan untuk mengidap hipertensi pada seorang yang memiliki orang tua pengidap hipertensi adalah sebesar 2 kali lipat bila dibandingkan dengan orang lain yang tidak memiliki kondisi hipertensi di orangtuanya. Sekitar $70-80 \%$ pasien hipertensi mempunyai riwayat hipertensi dalam keluarganya. Analisa data dengan chi square didapatkan nilai $p=0,000$ $(<0,005)$ yang artinya riwayat hipertensi berhubungan dengan kejadian hipertensi(Yuniarti et al., 2017)

Faktor dengan riwayat hipertensi 6,42 kali lebih mungkin mengalami 
preeklamsia dibandingkan wanita tanpa riwayat hipertensi. Tekanan darah tinggi pada ibu hamil dapat menimbulkan berbagai efek, mulai dari preeklamsia ringan hingga preeklamsia berat. Hipertensi selama kehamilan dibagi menjadi pre-eklampsia, pre-eklampsia, pre-eklampsia, dan hipertensi berat (ibu hamil pra-kehamilan sudah hipertensi dan bertahan selama kehamilan). Tanda dan gejala yang terjadi pada semua cara pengelolaan hipertensi tidak sama (Yuniarti et al., 2017).

Berbeda dengan penelitian dari Situmorang 2016 yang menyatakan bahwa hasil uji statistik diperoleh nilai $p$ value $=0,060 \quad(>0,005) \quad$ sehingga disimpulkan bahwa tidak terdapat hubungan antara riwayat hipertensi dengan kejadian preeklampsi pada ibu hamil(Yuniarti et al., 2017)

6. Kunjungan Antenatal Care

Dari 30 responden, lebih dari setengah $(60 \%)$ responden melakukan kunjungan antenatal care secara teratur dan kurang dari setengah (40\%) responden yang tidak rutin melakukan kunjungan antenatal care. Dari analisis didapatkan nilai t hitung untuk kunjungan antenatal care adalah 9,143 dengan tingkat kemaknaan $p=0,000 \quad(<0,005)$ yang artinya kunjungan antenatal care merupakan determinan dari kejadian preeklampsi dan eklampsi. Riwayat hipertensi menempati nilai tertinggi keenam dalam $t$ hitung sebagai determinan penyebab preeklampsi dan eklampsi pada ibu hamil trimester III di RS Prima Husada Sidoarjo.

Tidak sejalan dengan hasil penelitian dari Situmorang di tahun 2016 yang menyatakan bahwa dari hasil uji statistik diperoleh nilai $p$ value $=0,813(>0,005)$ yang kesimpulannya adalah tidak adanya hubungan antara pemeriksaan antenatal care dengan kejadian preeklampsi.Kunjungan antenatal secara teratur akan mudah melakukan deteksi dini untuk menemukan masalah maupun penyerta penyakit selama periode kehamilan. Sehingga bisa segera dilakukan antisipasi dan diatasi oleh Bidan maupun tenaga kesehatan lainnya.(Yuniarti et al., 2017)

Hasil berbeda ditunjukkan dari penelitian Yuniarti di tahun 2017, menunjukkan hasil $p$ value sebesar 0,656 $(>0,005)$ sehingga disimpulkan bahwa tidak terdapat hubungan antara keteraturan kunjungan selama kehamilan dengan kejadian preeklampsi pada ibu hamil(Yuniarti et al., 2017)

\section{SIMPULAN}

Usia ibu, tekanan arteri rata-rata, protein urin, riwayat hipertensi, dan pemeriksaan kehamilan merupakan faktor penentu kejadian preeklamsia 
pada ibu hamil tua di RS Prima Husada Sidoarjo. Semua determinan tersebut telah diidentifikasi di RS Prima Husada Sidoarjo sebagai faktor risiko terjadinya preeklamsia pada akhir kehamilan

Pentingnya deteksi dini untuk mencegah komplikasi pada kehamilan dan menghindari faktor-faktor yang menentukan kejadian preeklamsia pada ibu hamil.

\section{DAFTAR PUSTAKA}

Asmana, S. K., Syahredi, \& Hilbertina, N. (2016). Hubungan Usia dan Paritas dengan Kejadian Preeklampsia di Rumah Sakit Achmad Mochtar Bukittinggi. Jurnal Kesehatan Andalas, 5(3). http://jurnal.fk.unand.ac.id

Dan, P., Jawab, T., Kesehatan, T., Program, M., Nasional, K., Fakultas, A. A., Kesehatanuniversitas, I., \& Jember, M. (2018). PROSIDING SEMINAR NASIONAL 2018 ROLL OVER TEST SEBAGAI PREDIKSI PRE EKLAMSI PADA IBU HAMIL. In Prosiding Seminar Nasional (pp. 1-7).

Fajarsari, D., Prabandari, F., Kebidanan, A., \& Purwokerto, Y. (2016). PENGARUH PARITAS DAN INDEKS MASA TUBUH (IMT) TERHADAP KEJADIAN PREEKLAMSI DI KABUPATEN BANYUMAS. Bidan Prada: Jurnal Ilmiah Kebidanan, 7(2), 104-113.

Fatkhiyah, N., Kodiyah, \& Masturoh. (2016). DETERMINAN MATERNAL KEJADIAN
PREEKLAMPSIA (STUDI KASUS DI KABUPATEN TEGAL, JAWA TENGAH). The Soedirman Journal of Nursing), 11(1).

Fillandro, J., Setyawan, D., Ayu, I., Wiryanthini, D., \& Tianing, N. W. (2019). GAMBARAN KADAR PROTEIN URINE PADA IBU HAMIL PREEKLAMPSIA DAN EKLAMPSIA DI RSUP SANGLAH DENPASAR TAHUN 2017. In MEDIKA UDAYANA (Vol. 8, Issue 12, p. 2019). https://ojs.unud.ac.id

Kurniadi, A., Tanumihardja, T., \& Pradiptaloka, E. (2017). STATUS PROTEINURIA DALAM KEHAMILAN DI KABUPATEN SUMBA BARAT DAYA, NUSA TENGGARA TIMUR TAHUN 2016 Proteinuria Status in Pregnancy in Southwest Sumba District, East Nusa Tenggara in 2016. Jurnal Kesehatan Reproduksi, 8(1), 53-61. https://doi.org/10.22435/kespro.v8i1.63 32.53-61

Kusumawati, W., \& Ratna Wijayanti, A. (2017). GAMBARAN FAKTOR-FAKTOR RISIKO KEJADIAN PREEKLAMPSIA PADA IBU BERSALIN DENGAN PREEKLAMPSIA (Di RS Aura Syifa Kabupaten Kediri bulan Februari-April tahun 2016). Jurnal Kebidanan Dharma Husada, 6(2), 139146.

Mutiara, B., Amirus, K., Aryastuti, N., Wulandari, R., \& Sudirahayu, I. (2018). Analisis Faktor Risiko Yang Mempengaruhi Tekanan Darah Dan Protein Urine Pada Ibu Dengan 
Preeklampsi Di RSUD DR. H. Abdul Moeloek Provinsi Lampung 2017. Jurnal Kesmas, $1-8$. http://openjurnal.unmuhpnk.ac.id/index .php/JKMK

Phillips, J. K., McBride, C. A., Hale, S. A., Solomon, R. J., Badger, G. J., \& Bernstein, I. M. (2017). Examination of Prepregnancy and Pregnancy Urinary Protein Levels in Healthy Nulliparous Women. Reproductive Sciences, 24(3), 407-412.

https://doi.org/10.1177/1933719116657 198

Rahmaningtyas, I., Sendra, E., Kemenkes, P., Prodi, M., \& Kediri, K. (2018). Model Asuhan Kebidanan Berbasis Teori Helen Varney Dalam Deteksi Dini Prekelampsi Kehamilan Di RSIA Citra Keluarga Kota Kediri (Vol. 2, Issue 1).

RI, K. K. (2018). Laporan Riskesdas 2018. Journal of Chemical Information and Modeling, 53(9), 1689-1699. https://doi.org/10.1017/СВ0978110741 5324.004

Rumelia Lubina Sembiring. (2018). Aktivitas Fisik, Stress, Mean Arterial Pressure (MAP), Roll Over Test (ROT) Dan Kortisol Sebagai Prediktor Hipertensi Pada Kehamilan.

http://digilib.unhas.ac.id/uploaded_files /temporary/DigitalCollection/OWM1ZjFI
Njg1NmNiZWQ1Y2M3ZWI4ZTgwM2I1Nj

UwNDMzOWIzMDY5ZQ==.pdf

Sari, P., Hapsari, D., Dharmayanti, I., Kusumawardani, N., Teknologi, P., Kesehatan, I., Litbangkes, B., Ri, K., Percetakan, J., \& No, N. (2014). FAKTORFAKTOR YANG BERPENGARUH TERHADAP RISIKO KEHAMILAN "4 TERLALU (4-T)" PADA WANITA USIA 1059 TAHUN (ANALISIS RISKESDAS 2010). In Media Litbangkes (Vol. 24, Issue 3, pp. 143-152).

Situmorang, T. H., Damantalm, Y., Januarista, A., \& Sukri. (2016). FAKTOR-FAKTOR YANG BERHUBUNGAN DENGAN KEJADIAN PREEKLAMPSIA PADA IBU HAMIL DI POLI KIA RSU ANUTAPURA PALU. Jurnal Kesehatan Tadulako, 2(1), 1-11.

Yuniantika, W., Wardani, K., \& Mawarti, R. (n.d.). ANALSIS FAKTOR-FAKTOR RISIKO YANG MEMPENGARUHI TERJADINYA PREEKLAMSIA ATAU EKLAMSIA DI RSU PKU MUHAMMADIYAH YOGYAKARTA.

Yuniarti, F., Wijayati, W., \& Ivantarina, D. (2017). Analisis Perilaku Kesehatan Dan Faktor Resiko Kejadian Preeklampsia Pada Ibu Hamil Di Poliklinik Obstetri Gynekologi RSUD Kabupaten Kediri. Journal of Issues in Midwifery, 1(3), 117. 